\title{
"The impact of organizational culture on job performance: a study of Saudi Arabian public sector work culture"
}

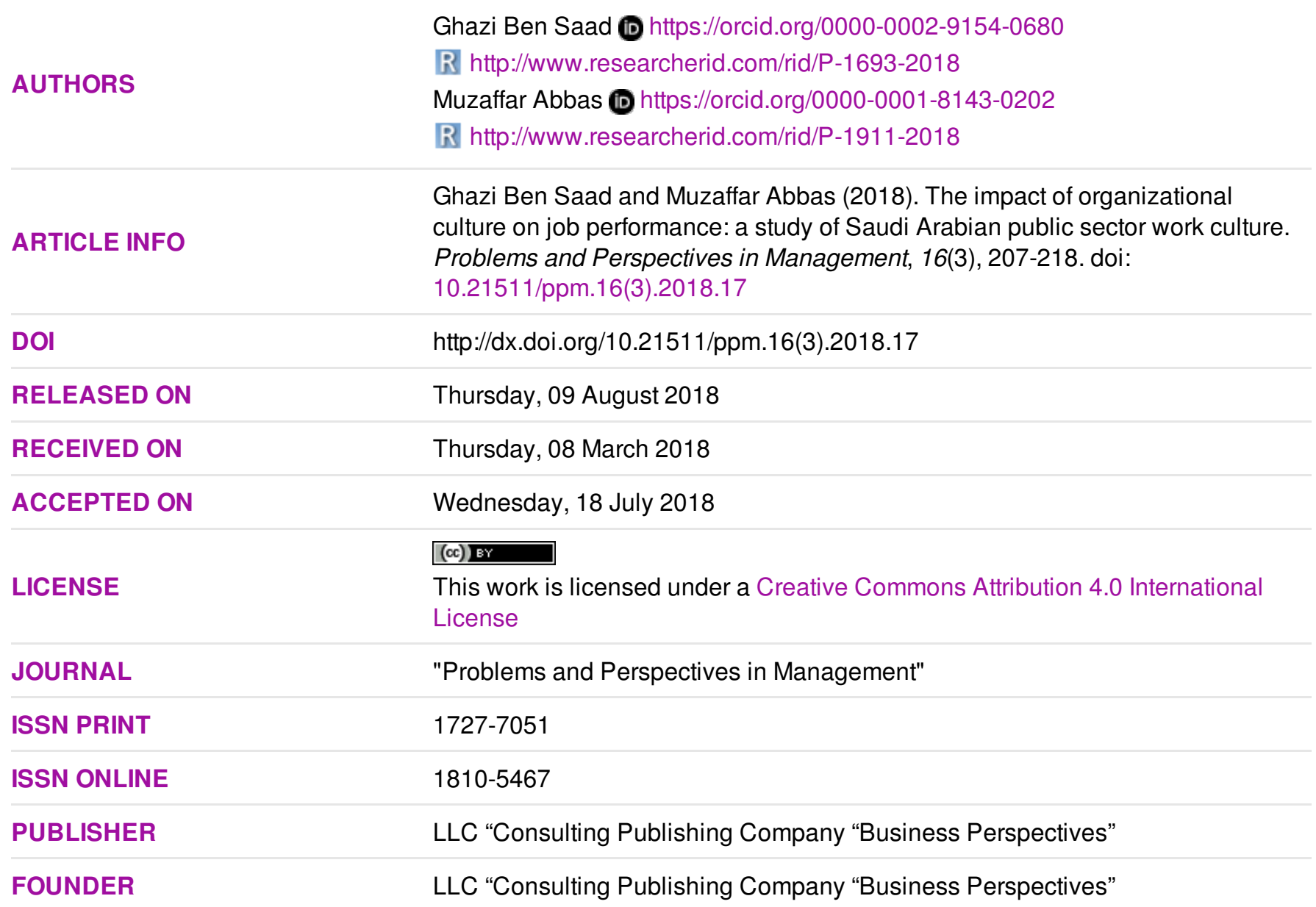

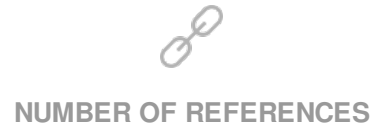

44
NUMBER OF FIGURES

1

\section{ニニะ}

NUMBER OF TABLES

10

(C) The author(s) 2022. This publication is an open access article. 


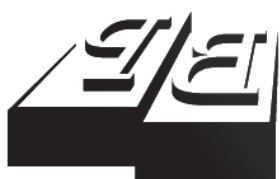

BUSINESS PERSPECTIVES

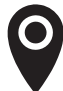

LLC "CPC "Business Perspectives" Hryhorii Skovoroda lane, 10, Sumy, 40022, Ukraine

www.businessperspectives.org

Received on: $8^{\text {th }}$ of March, 2018 Accepted on: $18^{\text {th }}$ of July, 2018

(c) Ghazi Ben Saad,

Muzaffar Abbas, 2018

Ghazi Ben Saad, Ph.D. Management, Assistant Professor of Management, Department of Business Administration, Community College, Prince Sattam Bin Abdulaziz University, Alkharj, Kingdom of Saudi Arabia.

Muzaffar Abbas, MS-Management, Lecturer, Department of Business Administration, Community College, Prince Sattam Bin Abdulaziz University, Alkharj, Kingdom of Saudi Arabia.

\section{()ㅜ(i)}

This is an Open Access article, distributed under the terms of the Creative Commons Attribution 4.0 International license, which permits unrestricted re-use, distribution, and reproduction in any medium, provided the original work is properly cited.

\section{THE IMPACT OF ORGANIZATIONAL CULTURE ON JOB PERFORMANCE: A STUDY OF SAUDI ARABIAN PUBLIC SECTOR WORK CULTURE}

\begin{abstract}
This research aims to assess direct and indirect influences of organizational culture on job performance, as well as to evaluate the impact of each sub-element of organizational culture on such performance. It is argued that employees performance derives, on the one hand, from a long-term perspective related to changes that organizations manage and implement during their process of growth. A second dimension of organizational culture can be given through organizational values, routines and distinctive aspects of culture that allow organizations to create solid competitive advantages. Since most studies in this field were held in Western work cultures, this paper will be devoted to the analysis of this relationship within an Arabic cultural environment and more specifically within a Saudi context. A quantitative study tool, based on a comprehensive research questionnaire, was used and the sample was selected from various government departments being operative in Alkharj. The findings indicate a positive relationship between organizational culture and job performance. Likewise, four organizational culture sub-elements, namely Managing Change, Achieving Goals, Coordinating Teamwork and Cultural Strength, were found affecting positively on job performance, but with varying and distinct intensity. Only Customer Orientation was found negatively associated with job performance.
\end{abstract}

\section{Keywords}

organizational culture, change management, cultural strength, group cohesion, job performance, Saudi Arabia

\section{JEL Classification M10, M14}

\section{INTRODUCTION}

Most recent researches in the field of management and behavioral studies have an influence on conceptual and empirical linkage of organizational culture with organizational performance, as well as with individual job performance. However, most of these organizational culture studies were mainly elaborated within Western work environments. There has been little or no evidence to have similar studies being conducted in Arabian culture generally and Saudi Arabian work culture particularly. In Western work cultures, it is an established argument that organizational culture has direct or indirect, individual, as well as collective performance of the teams and organizations. A number of questions arise about the generalization of those findings and their implementation in other work cultures. Currently, this work culture is in process of transformation from a government endowment economy to a private competitive industrial economy. Indeed, during the last couple of years, the Saudi Arabian economy is transforming from government-controlled economy to a market control economy. The Saudi leadership vision 2030 has a comprehensive renovation plan for the economy and a number of socioeconomic measures are taking place in all facets of the economy. These measures, at a larger level, include value addition tax, withdrawal of subsidies from oil and electric- 
ity, and implementation of Saudization Plan vigorously. In view of these transformational processes of the economy, researchers expect that there will be tremendous cultural changes in the organizational settings and resultantly there will be impacts on the performance of individuals and consequently on organizations, specifically on completion of National Transformational Plan 2020. Prince Sattam Bin Abdulaziz University, as a part of public sector organizations, depends on policy guidelines and budgeting provisions from Ministry of Higher Education of Saudi Arabia. Internally, the organization has a culture of mutual trust, collective decision-making process through teamwork, encouraging innovation, state of the art information technology and infrastructure support for academic and research excellence. Rewards for excellence in academic and research performance are prevalent in the university. Currently, the university has approximately an equal ratio of expats and Saudis at work, which makes a blend of performance culture. In a couple of years, when transformational process of saudization is complete, there will be a new work culture, which will have no effect of foreigner's cultural values and efficacies of work. We feel that this is the right time to carry out such studies to see the impact of organizational culture and its sub-elements on the performance of the individuals in the public sector work environment, which has a direct influence on this transformation. The aim of this research is to establish a baseline of influencing cultural variable in the performance process and to create academic literature for subsequent studies. This study will examine the culture-performance relationship in a Saudi public sector university and will predict probable impacts on performance due to cultural changes. Our findings would facilitate the organization to prepare and implement remedial measures timely.

\section{LITERATURE REVIEW}

Edith Penrose (1995) identifies the concepts of core and network as two main promising organizational paradigms that organizations and researchers should rely on, since they shape the behavior of markets and the effects of 'free market' competition. She highlights that the organizations which focus on adapting to their core values and are able to develop network of existence will be the future of the market. Indirectly this gives an insight to the establishment of organizational culture based on core values and her conceptual argumentation gives rise to the linking of the organization culture and its elements to the organizational performance. The organization as a nexus of social groups has become the prevailing idea within all recent researches, where cultural capabilities and core competencies are the main determinants in shaping the process of the growth of organizations and henceforth their performance. One of the earliest studies lies in Hofstede's (1980) seminal work, where he assimilates organizational culture to the software of the mind. In fact, it is in organizational culture that one can find the origin and eventual purpose of any analysis dealing with firms, their development, as well as their performance. Specifically, Hofstede argues that differences in strategies, behaviors and performances emerge from differences in organizational cultures pertaining actually to differences in national cultures.
Wallach (1983) identified the basic facets of organizational cultures and clarified the Hofstede's (1980) findings about the culture. Peter and Waterman (1982) found a significant link between strong culture and high financial performance. The actions of the performers in a cultural setting reflect their configuration of the learned mind processes throughout the span of their lives and this configuration tendency creates differences among individuals (Kotter \& Heskett, 1992). Organizational culture and organizational practices co-exists, which affects the socioeconomic value created by firms. Schein (2006) emphasizes that a right and strong corporate culture is the major key that enables firms to solve their problems, adapt their managerial style and reach effectiveness and expected levels of performance. Most researchers have almost agreed in conceptualizing organizational culture as a whole mechanism of interconnected and interdependent set of commonly shared values that systematically determine organizational behaviors, and norms adopted in solving problems and reaching higher levels of success. Kandula (2006) carried out a study and recommended the organizations to exhibit a strong work culture to gain tremendous, consistent and plausible performance. A winning strategy cannot be extended to new situations with success unless differences in organizational cultures are taken into account (Deal \& Kennedy, 1982), otherwise the organizations cannot guarantee the same levels 
of performance, and it may even become counterproductive. Therefore, organizational culture must adapt over time with dynamic situations in order to cope up with intra- and inter-organizational transformations to meet with people's backgrounds, expectations and satisfactions. In this paper, we will discuss the impact of organizational culture and all its sub-elements on employee job performance within a public sector. This evaluation is essential, because it makes the organizational decision makers to realize the strings exists in organizational culture and employee performance relationship that guides them to evolve such strategies, which would lead to achieve organizational strategic objectives.

\subsection{Organizational culture and performance}

Aycan et al. (1999) argued that organizational culture at its peak becomes a source of competitive advantage for organizations, since it affects commitment of people at work, both individual and collective process of learning and capability development, and it arises from the underlying assumptions, beliefs, norms, values and attitudes. In sum, as argued by Pettigrew (1979), organizational culture explains how employees think and make decisions that ultimately affect the performance. Lund (2003) while discussing the employee-related performance variables, recommended the management of the organizations to clearly identify the performance variables of the employees such as task knowledge, task expectation, extents of achievement and satisfactory levels of performance, and correlate these with the clearly identified dimensions of the corporate culture. Furthermore, he recommends and suggests that organization culture prevails and moves in a unified direction only if the management clearly establishes the corporate culture dimensions, explain them to the organizational members vividly, and all employees agree on their mutual association. Ogbonna and Harris (2000) research findings positively associated organizational culture with corporate performance. The researchers like Shahzad et al. (2013) elaborate organization culture as the key influencer of the performance and establish that a strong organization culture is a great source of performance excellence and consistent achievements. Kozlowski and Klein (2000) emphasize upon the presence of strong organ- izational culture based on true value and belief systems in order to gain sustainability in higher performance. Denison (1990) links management decisions and behavioral practices to the outcome of commonly shared norms, values and beliefs that an organization transforms and experiences since its inception. The set pattern of works and handling issues in management decisions are the reflection of organizational norms system. Brown (1998) establishes that organizations are the outcomes of experiences and experiences make learning, which largely develop such norms, values and procedures that ensure a long-term presence of the organization in the field. He clearly establishes the presence of strong organizational cultural values to assure consistent performance.

The study of organizational culture has significance when it has correlation with the performance in order to improve actions (Alvesson, 1990). Barney (1986) explains that core values encourage creativity, innovativeness, higher achievements and flexibility in firms. The most common definition of performance explains it as the degree or extent of achievement of pre-assigned goals (Shields \& Brown, 2015) and each organization has to: firstly, determine measurable goals; secondly, link the abilities and competencies of the employees to these goals and; thirdly, provide the employees with sufficient resources to expect achievement of goals. Mathematically this can be described as: Performance $=($ Motivation X Employee competence X Resources) (Griffin \& Moorhead, 2011). The organizations are supposed to prepare and train their employees in such a way that they are fully abreast of the task demands from the organizations and they are able to link their abilities to specific actions so as they can contribute to the performance of the organization. In management literature, performance refers to the degree or extent of achievement of pre-established goals, but some scholars (Roe \& Ester, 1999) emphasize the fact that performance can be identified and measured through two main dimensions; action dimension and the output dimension and develop a linear relationship in which output becomes dependent on actions. In this argument, the performance depends upon actions of the employees. Likewise, financial performance parameters in the organization also depend upon the actions taken by the employees and their respective achieve- 
ments relate to the degree of achievement of mission and strategic objectives assigned to individuals and groups at work (Peter \& Waterman, 1982). The individual performance improvements plans may work effectively if the organization manipulates organizational culture and commonly share such value system that encourages employee, assures openness, and promulgates transparency and fairness. Thus, decision makers aspiring to have better individuals, as well as teams performance, must strive to establish an aspiring work culture (Cameron \& Quinn, 2011). Manetje and Martins (2009) recommend researchers to analyze and understand the cultural impacts on performance before carrying out any studies, which measure organizational performances. Al-Matari and Omira (2017) carried out a study in Saudi Arabia to examine the relationship between organization culture and performance in the public sector environment and collected responses from 384 samples, their findings indicated a positive relationship between the two. Kang and Stewart (2007) also positively link conducive work culture and higher organizational, as well as individual performance. We find studies from Ouchi (1981) to Al-Matari and Omira (2017), which have studied performance vis-à-vis work cultures. Despite the fact that there exist divergent views in past research about organizational culture and employees, as well as business performance studies, but majority of researcher agree to have observed cultural impacts on performance. These studies surely validate to carryout similar researches in such work environments that remain unattended from the researchers. Therefore, we can form the research hypothesis asfollows:

\section{H1: Organizational culture positively influences job performance.}

\subsection{Managing Change and performance}

One of the major characteristics of internal and external environments lies in their continuous change aspect. It has become necessary for organization to adapt and adjust their strategic behavior according to changes that they face. Burnes (2004) discussed the presence of change in every action of the organization, and argues that for each change, there appears resistance that destroys the change initiatives. Oreg (2003) established that employ- ees who opt for resistance are extremely difficult to come up with effective performance. Therefore, leaders are always facing such employees where an efficient communication strategy may be effective in handling them. Change and organizational strategies exist together and effective change management can have positive influence on the performance of employees (Kunze et al., 2013). In a public sector environment, change becomes more difficult due to involvement of top to bottom policies and decisions orientation. We form our hypothesis as follows:

H2: Managing Change actions of the organization positively influence the job performance of the employee.

\subsection{Achieving Goals orientations and performance}

Collective performance has the double advantage of increasing cohesion and positive competition between employees. It is argued for example that goals orientations very likely increase cognitive abilities of individuals, which positively affects their learning and performance. Moreover, achieving goals orientations incites employees to aspire to accomplish difficult or uncertain tasks, which eventually helps them to maintain high standards of performance (Porath \& Bateman, 2006). The organizational leaders encourage the efficacies of such employees who aspire to have effective goals orientation and there has been a positive link between the performance and goals orientation of the employee (Janssen \& Van-Yperen, 2004). Specifically, in the Saudi cultural context, it is more important for individuals to not deceive and disappoint the group than to succeed alone. It is the role of organizations to pave the way for individuals desiring to acquire new skills, to not avoid critical or uncertain situations and to improve their capabilities and competencies. Moreover, employees who achieve goals are very often concerned with feedback and others' evaluation and even judgment. With positive acknowledgment comes higher performance. Vandewalle et al. (2004) positively associated goals orientation with higher performance. We form our hypothesis as follows:

H3: Achieving Goals orientations positively impacts on the job performance of the employee. 


\subsection{Coordinating Teamwork and performance}

Coordination process is essential in building up organizational culture since it necessitates providing employees with the firm's strategic issues and objectives. Coordinating teamwork is relevant in designing the optimal structure of the organization where each member can identify his expertise according to what he is expected to achieve. Consequently, members of each group would be able to recognize complementarities between their practices and outcomes. Teamwork is thereby the key to enhance individual and collective learning which affects organizational performance.

Stewart and Barrik (2000) found indeed a positive relationship between teamwork and performance. We form our hypothesis as under:

H4: Coordinating Teamwork positively influences job performance of the employee.

\subsection{Customer Orientation and performance}

Customer orientation can be defined as managers' guide towards the implementation of strategies that meet with customers wants and needs and which allows organization to create the appropriate (added) value. Employees, on the other hand, are conscious of the fact that the evaluation of their job performance is tightly connected to customer satisfaction. In a university environment, students and labor market organizations are direct or indirect customers of the institution. Brown et al. (2002) argued about the positive linkage of customer orientation and job performance in a service industry. So, the organizations are supposed to strongly link employee's actions with the customer focus in order to obtain higher performance. We form our hypothesis as follows:

H5: Customer Orientation improves job performance of the employee.

\subsection{Cultural Strength and job performance}

Organizational culture encompasses values, norms and behaviors. It also describes and determines both socio-cognitive and socio-cultur- al environment of an organization. Strong culture leads to strong identity, which gives a certain feeling of security to employees, as if they were protected by their corporate structure, and encourages them to be committed to this identity. Strong culture, on the other hand, reflects a high degree of control by leaders and hierarchy to variables related to competition and affecting global performance. Organizational culture should be regarded at the same time as an asset and as a resource. Cultural strengths simply represent a competitive advantage. Established organizational norms and behaviors are used as strategic resources with the potential to create and implement improved organizational routines in order to deliver sustainable competitive advantages. The sustainability of these latter depends in fact on the extent to which organizations succeed in offering appropriate internal environment to employees. A good use of cultural strengths provides cues in order to reach desirable behaviors and performance. Organizations do not only manage employees; they lead them to make cultural strengths prolific in their process of knowledge-based learning, capability development and performance enhancement. Lund (2003) established a positive link with cultural strength and job performance, which eventually leads to higher collective performance.

H6: Cultural Strength in the organization positively influence the job performance of the employee.

\subsection{Research model}

A number of research models are present in the past studies, which link the performance evaluation in presence of the impact of organizational cultural dimensions. Deshpande et al. (1993) recommended an organizational culture composed of the elements such as competitive, innovative, and bureaucratic and community culture. Another common model in use is of Denison (1996) that evaluates culture-performance relationship with its four sub-elements such as Involvement, Consistency, Adaptability and Mission. We have also considered the most common Hofstede's (1980) model that was a robust model for past researches but its elements were good to measure national cultures. Sashkin and Rosenbach (1996) model of cultural assessment was also applied in many of the past 


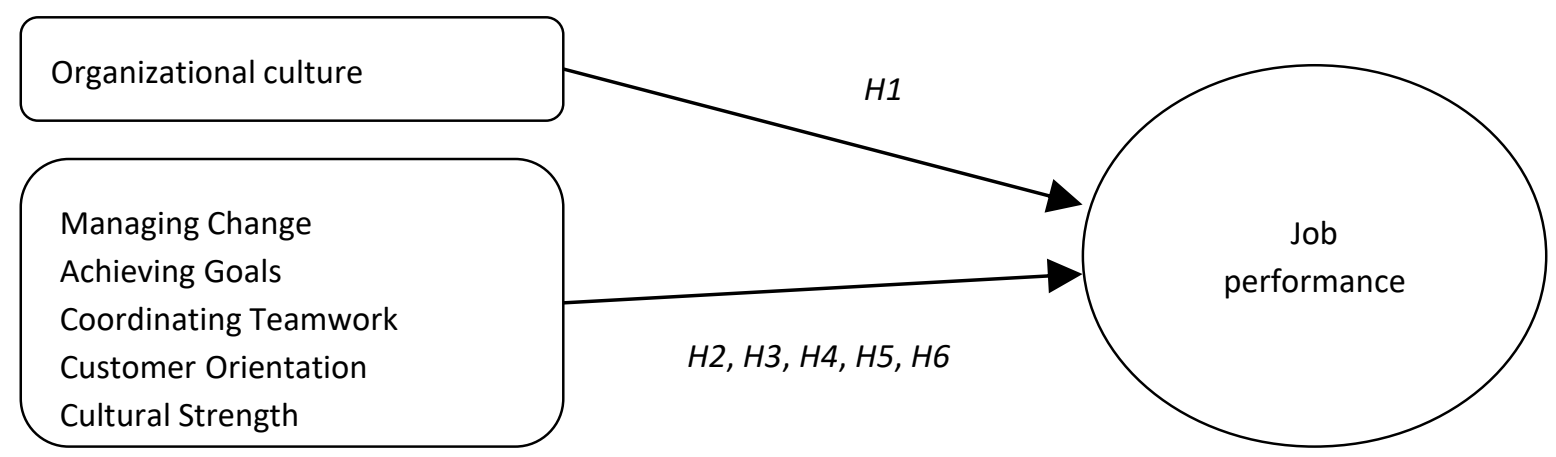

Figure 1. Research model

researches to assess the organizational cultural elements. We have also evaluated the model used by Ogbonna and Harris (2000) in their study to assess the relationship between organization culture and performance. They used a modified version of these models and argued that the Denison's model focused on the direct relationship of the organizational culture elements and the financial performance of the company, and it did not take care of the indirect impacts of the cultural elements. Likewise, Brewer and Venaik (2012) criticized the use of Hofstede's model in organizational cultural studies and recommended that Hofstede model was merely a tool to assess national cultures. Given these discussions, we consider it fit to apply (Sashkin \& Rosenbach, 1996) model in assessment of the organizational culture in relation with the job performance of the employees. Given this discussion, we draw our research model as under in which $H 1$ studies the collective and overall impact and the sub elements have also been assessed individually and collectively as $\mathrm{H} 2, \mathrm{H} 3, \mathrm{H} 4$ and $\mathrm{H} 5$. All five sub-elements are related to our research, but one element (customer orientation) was a little bit modified to make it useable in an academic environment.

\section{METHODOLOGY}

In this research, we have applied a survey design research methodology to obtain responses from the respondents on a questionnaire, which has two main parts. The first part includes the general information about the respondents such as tenure, gender, marital status, age and education, whereas the second part includes questions about the research variables such as organization culture and job performance. The organizational culture assessment questionnaire (Sashkin \& Rosenbach, 1996) includes 30 questions to obtain the responses of organizational culture, as well as its sub-variables such as managing change, achieving goals, coordinating teamwork, customer orientation and cultural strength. The scale after collection of data was aligned as referred in the scale development process by the authors and in the data process, the answers were appropriately reversed as directed. The job performance as a variable was also assessed through 21 questions at a Likert scale of 5, where one (1) denoted as completely disagree and five (5) denoted as completely agree (Williams \& Anderson, 1991). We have also used this scale to measure the overall job performance of the employee.

The study population of the research consisted of all the employees, both male and females, working in government departments in Alkharj area of Saudi Arabia. But for the purpose of convenience, the research sample includes the respondents from faculty members and employees working in Prince Sattam Bin Abdulaziz University, as well as the employees (male and female) working in various colleges. The university is among the biggest government institutions in Alkharj area, as well as its sub-campuses based in Hotat Bani Tamim, Alsulayel and Wadi Aldawasser. The employees belong to various nationalities and settle into one work culture. We have floated a total of 250 serially numbered questionnaires to the respondents out of which we received back 198 questionnaires, which constituted a response rate of approximately $79 \%$. However, in pursuit of better response rate, we followed the respondents successively. From the total questionnaires we received back, the questionnaires, which did not have complete information, or they were not considered valid for 
Table 1. Descriptive statistics

\begin{tabular}{|c|c|c|c|c|c|c|c|c|c|c|}
\hline \multirow[b]{2}{*}{ Description } & \multirow[b]{2}{*}{ N statistic } & \multirow{2}{*}{$\begin{array}{c}\text { Range } \\
\text { statistic }\end{array}$} & \multirow{2}{*}{$\underset{\text { statistic }}{\text { Minimum }}$} & \multirow{2}{*}{$\begin{array}{c}\text { Maximum } \\
\text { statistic }\end{array}$} & \multirow{2}{*}{$\begin{array}{l}\text { Mean } \\
\text { statistic }\end{array}$} & \multirow{2}{*}{$\begin{array}{c}\text { Std. } \\
\text { deviation } \\
\text { statistic }\end{array}$} & \multicolumn{2}{|c|}{ Skewness } & \multicolumn{2}{|c|}{ Kurtosis } \\
\hline & & & & & & & Statistic & $\begin{array}{c}\text { Std. } \\
\text { error }\end{array}$ & Statistic & $\begin{array}{c}\text { Std. } \\
\text { error }\end{array}$ \\
\hline College name & 176 & 7 & 1 & 8 & 4.82 & 2.400 & -.006 & .183 & -1.235 & .364 \\
\hline Years of service & 176 & 3 & 1 & 4 & 2.52 & 1.079 & -.004 & .183 & -1.264 & .364 \\
\hline Nationality & 176 & 7 & 1 & 8 & 2.91 & 2.430 & .987 & .183 & -.577 & .364 \\
\hline Male or female & 176 & 1 & 1 & 2 & 1.20 & .400 & 1.522 & .183 & .320 & .364 \\
\hline Marital status & 176 & 3 & 1 & 4 & 1.91 & .527 & 1.083 & .183 & 5.980 & .364 \\
\hline Age in years & 176 & 4 & 1 & 5 & 2.30 & .959 & .620 & .183 & .285 & .364 \\
\hline Qualification & 176 & 4 & 1 & 5 & 2.90 & 1.233 & -.284 & .183 & -1.156 & .364 \\
\hline Valid N (listwise) & 176 & - & - & - & - & - & - & - & - & - \\
\hline
\end{tabular}

the purpose of this research, were discarded and finally a total of 176 numbers were considered valid for this research, because these had complete information and apparently were devoid of any bias. It is important to mention that Saudi nationals were 79 and expatriates were 97 from the respondents. So, a good mix of both locals and expatriates constitutes a true unbiased preposition of the responses. Table-1 below is a highlight of numbers, means, standard deviations, skewness, kurtosis.

\section{Model 1. Analysis (overall study)}

Reliability analysis of the scales is the most important step to ensure that the work being undertaken is in line and consistent with past research or otherwise. We have used SPSS 16.0 and applied Cronbach's Alpha test to ensure that the scale is reliable and can be used for further testing. In both scales, we have found Cronbach's Alpha value as 0.846 for 30 items of the organizational culture scale and 0.711 for 21 items of the job performance scale. Furthermore, the statistician has agreed to accept reliability, in social sciences, if Cronbach's Alpha value is greater than .70. These values of Cronbach's Alpha as shown in Table 2 give us confidence to continue with the scales for our further results.

Table 2. Reliability analysis

\begin{tabular}{|c|c|c|c|c|c|}
\hline \multicolumn{3}{|c|}{$\begin{array}{c}\text { Reliability statistics: } \\
\text { organizational culture scale } \\
\end{array}$} & \multicolumn{3}{|c|}{$\begin{array}{c}\text { Reliability statistics: job } \\
\text { performance scale }\end{array}$} \\
\hline 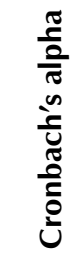 & 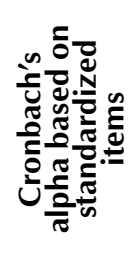 & $\begin{array}{l}\stackrel{n}{E} \\
\stackrel{\Xi}{ \pm} \\
\stackrel{0}{0} \\
\mathbf{Z}\end{array}$ & 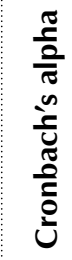 & 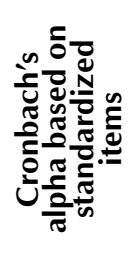 & $\begin{array}{l}\stackrel{n}{E} \\
\stackrel{ \pm}{ \pm} \\
\overline{0} \\
\mathbf{Z}\end{array}$ \\
\hline .846 & .851 & 30 & .711 & .771 & 21 \\
\hline
\end{tabular}

ANOVA test of respective scales also appeared significant at confidence value $p=0.05$ as shown in Tables 3 and 4. Significance in ANOVA shown in last column determines the accuracy of the model variables and their associated relationships.

Table 3. ANOVA: Organizational culture scale

\begin{tabular}{l|c:c|c:c|c}
\hline Description & $\begin{array}{c}\text { Sum of } \\
\text { squares }\end{array}$ & df & $\begin{array}{c}\text { Mean } \\
\text { square }\end{array}$ & F & Sig \\
\hline Between people & 1134.939 & 175 & 6.485 & - & - \\
\hline \multicolumn{6}{c}{ Within people } \\
\hline Between items & 503.049 & 29 & 17.347 & 17.410 & .000 \\
Residual & 5056.617 & 5075 & .996 & - & - \\
Total & 5559.667 & 5104 & 1.089 & - & - \\
\hline Total & 6694.606 & 5279 & 1.268 & - & - \\
\hline
\end{tabular}

Note: Grand mean $=3.31$.

Table 4. ANOVA: Job performance scale

\begin{tabular}{l|c:c:c:c|c}
\hline Description & $\begin{array}{c}\text { Sum of } \\
\text { squares }\end{array}$ & df & $\begin{array}{c}\text { Mean } \\
\text { square }\end{array}$ & F & Sig \\
\hline $\begin{array}{l}\text { Between } \\
\text { people }\end{array}$ & 557.558 & 175 & 3.186 & - & - \\
\hline \multicolumn{5}{c}{ Within people } \\
\hline Between items & 3695.598 & 20 & 184.780 & 200.325 & .000 \\
Residual & 3228.402 & 3500 & .922 & - & - \\
Total & 6924.000 & 3520 & 1.967 & - & - \\
\hdashline Total & 7481.558 & 3695 & 2.025 & - & - \\
\hline
\end{tabular}

Note: Grand mean $=3.60$.

In the next step of our analysis, we carried out the descriptive statistics analysis in SPSS and found the following results as shown in Table 5 . The purpose of this test was to evaluate the variables for normality. We observe that the values of skewness and kurtosis are in accordance with the acceptable range suggested in literature. Hair et al. (2012) establish that the value of skewness must fall in between the range of \pm 1 and as suggested by MacGillivray and Balanda (1988), the value of kurtosis must be within \pm 3 . In both cases, our values are within the acceptable limits. 
Table 5. Descriptive statistics

\begin{tabular}{|c|c|c|c|c|c|c|c|c|c|}
\hline \multirow[b]{2}{*}{ Variables } & \multirow{2}{*}{$\underset{\text { statistic }}{\text { Minimum }}$} & \multirow{2}{*}{$\begin{array}{l}\text { Maximum } \\
\text { statistic }\end{array}$} & \multirow{2}{*}{$\begin{array}{c}\text { Mean } \\
\text { statistic }\end{array}$} & \multirow{2}{*}{$\begin{array}{l}\text { Std. deviation } \\
\text { statistic }\end{array}$} & \multirow{2}{*}{$\begin{array}{l}\text { Variance } \\
\text { statistic }\end{array}$} & \multicolumn{2}{|c|}{ Skewness } & \multicolumn{2}{|c|}{ Kurtosis } \\
\hline & & & & & & Statistic & $\begin{array}{c}\text { Std. } \\
\text { error }\end{array}$ & Statistic & $\begin{array}{c}\text { Std. } \\
\text { error }\end{array}$ \\
\hline Performance & 1 & 5 & 3.50 & 1.080 & 1.166 & -.468 & .183 & -.324 & .364 \\
\hline $\begin{array}{l}\text { Organizational } \\
\text { culture }\end{array}$ & 1.60 & 4.60 & 3.1653 & .54779 & .300 & -.029 & .183 & .141 & .364 \\
\hline Valid N (listwise) & - & 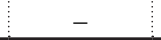 & - & 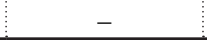 & - & 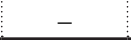 & 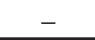 & - & 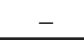 \\
\hline
\end{tabular}

Table 6. Correlation between the variables

\begin{tabular}{c|c|c|c}
\hline Test & Variables & Performance & Organizational culture \\
\hline \multirow{2}{*}{ Pearson correlation } & Performance & 1.000 & .518 \\
\hdashline$\ldots \ldots y$ & .518 & 1.000 \\
\multirow{2}{*}{ Sig. (1-tailed) } & Organizational culture & - & .000 \\
& Performance & .000 & - \\
\hline
\end{tabular}

The correlation between the two variable such as organizational culture and performance appears to be 0.518 (Table 6) which substantiates the positive relationship between the two. Furthermore, one-tailed test also appeared significant in this case. This clearly indicates that organizational culture significantly gives positive rise to the job performance of the individuals if organization makes effort to enhance cultural orientation. Given these results, we are in a position to accept our first hypothesis $H 1$.

Table 7 below shows the model summary in which $R^{2}$ value appears to be 0.269 , which explains an approximate $26.9 \%$ increase in performance variance through the impact of the organizational culture, which is quite a plausible result. Overall this finding and the positive relationship $(r=0.518)$ of correlation make us comfortable in substantiating the influence of organizational culture on job performance.
The coefficient values of the total model as indicated in Table 8 exhibit the model significance, as well as the beta value as 0.518 , which is sufficient to make an understanding of the result that organizational culture has a positive impact on the performance.

\section{Model 2. Analysis (elements of organizational culture and performance relation)}

We have also carried out a detailed analysis of each of the sub-elements of organizational culture, one after the other, so as to establish their linkage as recommended in literature. This comes to discuss the existence of each element correlation with the dependent variable, as well as the existence of the significance between each element and the dependent variable. The following table shows the inter-item correlation matrix and the value of correlation is quite substantial to accept the relationship as significant.

Table 7. Model summary

\begin{tabular}{c|c|c|c|c|c|c|c|c|c|c}
\hline Model & $\mathbf{R}$ & R square & $\begin{array}{c}\text { Adjusted } \\
\text { R square }\end{array}$ & $\begin{array}{c}\text { Std. error of } \\
\text { the estimate }\end{array}$ & $\begin{array}{c}\text { R square } \\
\text { change }\end{array}$ & $\begin{array}{c}\text { F } \\
\text { change }\end{array}$ & df1 & df2 & $\begin{array}{c}\text { Sig. F } \\
\text { change }\end{array}$ \\
\hline 1 & $.518 a$ & .269 & .264 & .926 & .269 & 63.926 & 1 & 174 & .000 \\
\hline
\end{tabular}

Note: a. Predictors: (constant), organizational culture.

Table 8. Coefficients

\begin{tabular}{|c|c|c|c|c|c|}
\hline \multirow{2}{*}{ Model } & \multicolumn{2}{|c|}{ Unstandardized coefficients } & \multirow{2}{*}{$\begin{array}{c}\text { Standardized coefficients } \\
\text { Beta }\end{array}$} & \multirow{2}{*}{$\mathbf{t}$} & \multirow{2}{*}{ Sig. } \\
\hline & B & Std. error & & & \\
\hline 1 (constant)a & .266 & .410 & - & .648 & .518 \\
\hline Organizational culture & 1.022 & .128 & .518 & 7.995 & .000 \\
\hline
\end{tabular}

Note: a. Dependent variable: performance. 
Table 9. Inter-item correlation matrix

\begin{tabular}{|c|c|c|c|c|c|c|}
\hline Model 2. Variables & $\begin{array}{c}\text { Managing } \\
\text { Change }\end{array}$ & $\begin{array}{c}\text { Achieving } \\
\text { Goals }\end{array}$ & Teamwork & $\begin{array}{c}\text { Customer } \\
\text { Orientation } \\
\end{array}$ & $\begin{array}{l}\text { Cultural } \\
\text { Strength }\end{array}$ & \begin{tabular}{|c} 
Job \\
performance
\end{tabular} \\
\hline Managing Change & 1.000 & - & - & - & - & - \\
\hline Achieving Goals & -.121 & 1.000 & - & - & - & - \\
\hline Teamwork & .235 & -.025 & 1.000 & - & - & - \\
\hline Customer Orientation & .042 & .193 & .031 & 1.000 & - & - \\
\hline Cultural Strength & .140 & -.061 & .332 & -.057 & 1.000 & - \\
\hline Job performance & .245 & .251 & .324 & -.030 & .511 & 1.000 \\
\hline
\end{tabular}

Note: $\mathrm{N}=176$ and dependent variable: performance.

Table 10. Coefficients

\begin{tabular}{|c|c|c|c|c|c|c|}
\hline & \multirow[t]{2}{*}{ Model } & \multicolumn{2}{|c|}{$\begin{array}{c}\text { Unstandardized } \\
\text { coefficients }\end{array}$} & \multirow{2}{*}{$\frac{\text { Standardized coefficients }}{\text { Beta }}$} & \multirow[t]{2}{*}{$\mathbf{t}$} & \multirow[t]{2}{*}{ Sig. } \\
\hline & & B & Std. error & & & \\
\hline \multirow{6}{*}{2} & (Constant) & .147 & .390 & - & .376 & .007 \\
\hline & Managing Change & .213 & .069 & .191 & 3.088 & .002 \\
\hline & Achieving Goals & .311 & .059 & .320 & 5.236 & .000 \\
\hline & Teamwork & .142 & .066 & .140 & 2.171 & .001 \\
\hline & Customer Orientation & -.075 & .059 & -.078 & -1.277 & .203 \\
\hline & Cultural Strength & .427 & .060 & .453 & 7.158 & .000 \\
\hline
\end{tabular}

Note: a. Dependent variable: performance.

A deeper look of the correlation matrix shows that all elements of organizational culture such as Managing Change, Achieving Goals, Teamwork and Cultural Strength are positively correlated with job performance, except the customer orientation, which is negatively associated with job performance. This allows us to accept our hypotheses $\mathrm{H} 2, \mathrm{H} 3$, and $\mathrm{H} 5$, but reject $H 4$. These findings are obvious and consistent with the findings of past researches except $H 4$, which might be due to the fact that our sample belonged to public sector environment and there is restriction to follow the insight of the government to devise action strategies. Overall beta values as shown in Table 10 also indicates a positive movement of these elements except customer orientation, which has a negative beta value. Furthermore, all our results are significant at $p$-value less than .05 , but the findings of customer orientation are also insignificant due to which we reject our hypothesis $H 4$.

\section{CONCLUSION}

The higher education was in focus during the last decade in Saudi Arabia. Government has established a number of universities in Saudi Arabia in order to meet the needs of higher education of their masses. Currently there are 26 universities in Saudi Arabia, where 20 of them exist since 10 years at most and strive to gain proper ranking and recognition from all over the world. Prince Sattam Bin Abdulaziz University is one of these newly established universities and it is competing to be within top 10 universities of Saudi Arabia in terms of its academic, as well as research performance. Currently, it has about 2,500 academic staff to serve around 25,000 students, majority of these are for bachelor programs. The university gains its financial and policy support from the Ministry of Higher Education. The overall working culture of the university is based on mutual trust, teamwork, shared value system and respect, but within the legal framework provided by Ministry of Higher Education. The university emphasizes upon teamwork to organize and accomplish academic, as well as research achievements. It gains its forces of integration and cohesion from its societal value system. 
The results of our research indicate a positive association between organization culture and job performance. This finding is also consistent with those of Al-Matari and Omira's (2017) research, which was recently conducted in Saudi Arabia public sector environment. The null hypothesis that organizational culture influences the job performance has been proved statistically. Overall influence of organizational culture on job performance as identified in a number of past researches carried out in non-Arabic cultures (Aycan et al., 1999; Lund, 2003; Ogbonna \& Harris, 2000; Shehzad et al., 2013) have been substantiated in Saudi cultural environment as well. However, the impact of each element on the job performance was not found similar to these same researches. Specifically, the impact of customer orientation was found negatively associated with the job performance and this finding is contrary to the findings of Stewart and Barrik (2000). This might have been due to the influence of public sector environment top-to-bottom trigger down policies.

On the other hand, we have identified that cultural elements such as managing change influence ratio is $21.3 \%$, achieving goals influence ratio is $31.1 \%$, teamwork influence ratio is $14.2 \%$ and cultural strength influence ratio is $42.7 \%$. These statistical results highlight the presence of cultural impacts on performance. In view of these findings, we recommend the policy makers in the university to give more focus on strengthening the organizational culture as a first measure, then make plans to award and motivate the goals achievers, then prepare plans to envision the future of the organization after 2020 and lastly focus on teamwork to achieve desired goals. These four components can be actually regarded by top management as main regulators of individual and collective performances. Future studies can be carried out in order to evaluate separately the impact of each element of organizational culture on performance.

Henceforth, the university should make necessary measures in order to allow changes in the organization and appreciate goals' achievers. The most important steps are to enable teamwork strengthening better work ethics and organizational practices; these two dimensions would actually lead to better appreciation norms, values and beliefs to be commonly shared by the organization's members. We also recommend that similar studies should be carried out at a larger extent by focusing on the samples from both private and public sectors work environments. Likewise, a comparative analysis between findings from public and private sectors can provide government with interesting cues in order to raise public sector's performance. Indeed, this could be a starting point to implement a national system of innovation based on organizational culture.

\section{REFERENCES}

1. Al-Matari, E. M., \& Omira, B. (2017). The Mediating Effect of Organizational Commitment on the Relationship between Organizational Culture and Organizational Performance in Public Sector: Evidence form KSA. International Journal of Business \& Management Science, 7(1), 67-77. Retrieved from https://scholar. google.com/scholar?hl=en\&as sdt $=0 \% 2 \mathrm{C} 5 \& \mathrm{q}=\mathrm{Al}-\mathrm{Matari} \% 2 \mathrm{C}+\mathrm{E}$ + M. + and + Omira $\% 2 C+B .+\% 2820$ $17 \% 29$. + The+Mediating+Effect+of +Organizational+Commitment+o $\mathrm{n}+$ the+Relationship+between $+\mathrm{Or}$ ganizational+Culture+and+Organ izational+Performance+in+Public + Sector\%3A+Evidence+form $+\mathrm{KS}$ A.+International+Journal+of+Bus
iness+\%26+Management+Science $\% 2 \mathrm{C}+7 \% 281 \% 29 . \& \mathrm{btnG}=$

2. Alvesson, M. (1990). On the Popularity of Organizational Culture. Acta Sociologica, 33(1), 31-49. https://doi. org/10.1177/000169939003300103

3. Aycan, Z., Kanungo, R. N., \& Sinha, J. P. (1999). Organizational Culture and Human Resource Management Practices: The Model of Culture Fit. Journal of Crosscultural Psychology, 30, 501-526. https://doi.org/10.1177/002202219 9030004006

4. Barney, J. B. (1986). Organizational culture: can it be a source of sustained competitive advan- tage? Academy of management review, 11(3), 656-665. https://doi. org/10.5465/AMR.1986.4306261

5. Brewer, P., \& Venaik, S. (2012). On the Misuse of National Culture Dimensions. International Marketing Review, 29(6), 673-683. https://doi. org/10.1108/02651331211277991

6. Brown, A. D. (1998). Organizational culture (2nd ed). London: Financial Times Management. Retrieved from https://www.amazon.co.uk/Organisational-CultureFinancial-times-management/ dp/0273631470

7. Brown, Tom J., John C. Mowen, D. Todd Donavan, \& Jane W. Licata (2002). The customer orientation 
of service workers: Personality trait effects on self-and supervisor performance ratings. Journal of marketing research, 39(1), 110-119. Retrieved from http:// journals.ama.org/doi/abs/10.1509/ jmkr.39.1.110.18928? code $=$ ammasite

8. Burnes, B. (2004). Managing change: A strategic approach to organizational dynamics. Pearson Education. Retrieved from https:// trove.nla.gov.au/work/7265964

9. Cameron, K. S., \& Quinn, R. E. (2011). Diagnosing and changing organizational culture: Based on the competing values framework. John Wiley \& Sons. Retrieved from https://scholar.google.com/ scholar?hl=en\&as_sdt $=0 \% 2 \mathrm{C} 5 \& \mathrm{q}$ $=$ Cameron $\% 2 \mathrm{C}+\mathrm{K} .+\mathrm{S} . \% 2 \mathrm{C}+\% 26+$ Quinn\%2C+R.+E.+\%282011\%29. + Diagnosing+and+changing+org anizational+culture $\% 3 \mathrm{~A}+$ Based+ on+the+competing+values+fram ework.+John+Wiley+\%26+Sons. \&btnG $=$

10. Deal, T. E., \& Kennedy, A. A. (1982). Corporate cultures: The rites and rituals of organizational life. Reading T. Deal, A. Kennedy. Mass: Addison-Wesley, 2, 98-103. Retrieved from https://scholar. google.com/scholar?hl=en\&as_sd $\mathrm{t}=0 \% 2 \mathrm{C} 5 \& \mathrm{q}=\mathrm{Deal} \% 2 \mathrm{C}+\mathrm{T} .+\mathrm{E}$ .+and+Kennedy $\% 2 \mathrm{C}+\mathrm{A} .+\mathrm{A} .+-$ $\% 281982 \% 29 .+$ Corporate+Culture s.+Reading\%2C+Mass. $\% 3 \mathrm{~A}+$ Addi son-Wesley.\&btnG=

11. Denison, D. R. (1990). Corporate culture and organizational effectiveness. John Wiley \& Sons. Retrieved from https://scholar. google.com/scholar?hl=en\&as_sd $\mathrm{t}=0 \% 2 \mathrm{C} 5 \& \mathrm{q}=$ Denison $\% 2 \mathrm{C}+\mathrm{D} .+$ R.+\% $281990 \% 29 .+$ Corporate $+\mathrm{cu}$ lture+and+organizational+effecti veness.+John+Wiley+\%26+Sons. \&btnG $=$

12. Denison, D. R. (1996). What is the Difference Between Organizational Culture and Organizational Climate? A Native's Point of View on a Decade of Paradigm Wars. The Academy of Management Review, 21(3), 619-654. https://doi. org/10.2307/258997

13. Denison, D. R., \& Mishra, A. K. (1995). Toward a theory of organizational culture and effectiveness.
Organization science, 6(2), 204223. Retrieved from https://scholar.google.com/scholar?hl=en\&as_ $\mathrm{sdt}=0 \% 2 \mathrm{C} 5 \& \mathrm{q}=$ Toward $+\mathrm{a}+$ Theor $\mathrm{y}+\mathrm{of}+$ Organizational+Culture + an $\mathrm{d}+$ Effectiveness\&btn $\mathrm{G}=$

14. Deshpande, R., Farley, J. U., \& Webster, F. E. (1993). Corporate Culture, Customer Orientation and Innovativeness in Japanese Firms: A Quadrad Analysis. Journal of Marketing, 57, 23-37. Retrieved from https://www. hbs.edu/faculty/Pages/item. aspx?num $=2651$

15. Griffin, R. W., \& Moorhead, G. (2011). Organizational behavior. Cengage Learning. Retrieved from https://scholar.google.com/ scholar?hl=en\&as_sdt $=0 \% 2 \mathrm{C} 5 \& \mathrm{q}$ $=$ Griffin $\% 2 \mathrm{C}+\mathrm{R} .+\mathrm{W} . \% 2 \mathrm{C}+\% 26+\mathrm{M}$ oorhead\%2C+G.+\%282011\%29.+ Organizational+behavior.+Cengag e+Learning.\&btnG=

16. Hair, J. F., Sarstedt, M., Ringle, C. M., \& Mena, J. A. (2012). An assessment of the use of partial least squares structural equation modeling in marketing research. Journal of the academy of marketing science, 40(3), 414-433. Retrieved from http://citeseerx.ist.psu.edu/ viewdoc/download?doi=10.1.1.45 8.9537\&rep $=$ rep $1 \&$ type $=$ pdf

17. Hofstede, G. (1980). Culture and organizations. International Studies of Management \& Organization, 10(4), 15-41. https://doi.org/10.108 0/00208825.1980.11656300

18. Janssen, O., \& Van Yperen, N. W. (2004). Employees' goal orientations, the quality of leader-member exchange, and the outcomes of job performance and job satisfaction. Academy of management journal, 47(3), 368-384.

19. Kandula, S. R. (2006). Performance Management. New Delhi: Prentice Hall of India Private Limited. Retrieved from https://scholar.google.com/scholar?hl=en\&as_ $\mathrm{sdt}=0 \% 2 \mathrm{C} 5 \& \mathrm{q}=$ Kandula $\% 2 \mathrm{C}+\mathrm{S} .+$ R.+\%282006\%29.+Performance+ Management. $+\mathrm{New}+$ Delhi\%3A+P rentice+Hall+of+India+Private+Li mited.\&btnG $=$

20. Kang, D. S., \& Stewart, J. (2007). Leader-Member Exchange (LMX) Theory of Leadership and HRD: Development of Units of Theory and Laws of Interaction. Leadership \& Organization Development Journal, 28(6), 531-551. https://doi. org/10.1108/01437730710780976

21. Kotter, J. P., \& Heskett, J. L. (1992). Corporate Culture and Performance. New York: Free Press. Retrieved from https://www.hbs.edu/ faculty/Pages/item.aspx?num=139

22. Kozlowski, Steve, W. J., \& Katherine J. Klein (2000). A multilevel approach to theory and research in organizations: Contextual, temporal, and emergent processes. Retrieved from http://psycnet.apa. org/record/2000-16936-001

23. Kunze, F., Boehm, S., \& Bruch, H. (2013). Age, resistance to change, and job performance. Journal of Managerial Psychology, 28(7/8), 741-760. Retrieved from https:// doi.org/10.1108/JMP-06-20130194

24. Lund, D. B. (2003). Organizational Culture and Job Satisfaction. Journal of Business and Industrial Marketing, 18(3), 219-236. https://doi. org/10.1108/0885862031047313

25. MacGillivray, H. L., \& Balanda, K. P. (1988). The relationships between skewness and kurtosis. Australian \& New Zealand Journal of Statistics, 30(3), 319-337. https:// doi.org/10.1111/j.1467-842X.1988. tb00626.x

26. Manetje, O., \& Martins, N. (2009). The Relationship Between Organizational Culture and Organizational Commitment. Southern African Business Review, 13(1), 87-111. Retrieved from http://hdl. handle.net/10500/3964

27. Ogbonna, E., \& Harris, L. C. (2000). Leadership style, organizational culture and performance: empirical evidence from UK companies. International Journal of Human Resource Management, 11(4), 766-788. https://doi. org/10.1080/09585190050075114

28. Oreg, S. (2003). Resistance to change: Developing an individual differences measure. Journal of applied psychology, 88(4), 680-93. Retrieved from https://www.ncbi. nlm.nih.gov/pubmed/12940408

29. Ouchi, W. (1981). Theory Z: How American business can meet 
the Japanese challenge. Business Horizons, 24(6), 82-83. https://doi. org/10.1016/0007-6813(81)90031-8

30. Porath, C. L., \& Bateman, T. S. (2006). Self-regulation: from goal orientation to job performance. Journal of Applied Psychology, 91(1), 185.

31. Penrose, E. T. (1995). The Theory of the growth of the firm (3rd ed.). Oxford University Press. Retrieved from http://www.oxfordscholarship.com/view/10.1093/019828977 4.001.0001/acprof-9780198289777

32. Peter, T. J., \& Waterman, R. H. (1982). In search of excellence: Lessons from America's best-run companies. Warner Book, New York. Retrieved from https:// www.researchgate.net/publication/237068020_In_Search_of_ Excellence_Lessons_From_America's_Best-Run_Companies

33. On Studying Organizational Cultures. Administrative Science Quarterly, 24(4), Qualitative Methodology, 570-581. https://doi. org/10.2307/2392363

34. Roe, R. A., \& Ester, P. (1999). Values and work: Empirical findings and theoretical perspective. Applied psychology, 48(1), 1-21. Retrieved from https://scholar. google.com/scholar?hl=en\&as_sd $\mathrm{t}=0 \% 2 \mathrm{C} 5 \& \mathrm{q}=$ Roe $\% 2 \mathrm{C}+\mathrm{R} .+\mathrm{A} .+\%$ 281999\%29.+Values+and+Work\% $3 \mathrm{~A}+$ Empirical+Findings+and $+\mathrm{Th}$ eoretical+Perspective.+Applied+ Psychology\%2C+48+\%281\%29\% $2 \mathrm{C}+1-21.8 \mathrm{btn} \mathrm{G}=$

35. Sashkin, M., \& Rosenbach, W. E. (1996). Organizational culture assessment questionnaire (Unpublished manuscript). Washington, DC: The George Washington University. Retrieved from http:// new.leadingandfollowing.com/ documents/OCAQParticipantManual.pdf

36. Schein, E. H. (1984). Coming to a new awareness of organizational culture. Sloan management review, 25(2), 3-16. Retrieved from http://www.sietmanagement.fr/ wp-content/uploads/2016/04/culture_schein-1.pdf

37. Schein, E. H. (2006). Organizational culture and leadership (Vol.
356). John Wiley \& Sons. Retrieved from https://scholar.google. $\mathrm{com} / \mathrm{scholar}$ ?hl=en\&as_sdt $=0 \% 2 \mathrm{C}$ $5 \& \mathrm{q}=$ Schein $\% 2 \mathrm{C}+\mathrm{E} .+\mathrm{H} .+\% 28200$ $6 \% 29 .+$ Organizational+culture $+\mathrm{a}$ nd+leadership $+\% 28$ Vol. $+356 \% 29$. +John+Wiley+\%26+Sons.\&btnG=

38. Schein, E. H. (2010). Organizational culture and leadership (Vol. 2). John Wiley \& Sons. Retrieved from https://scholar.google.com/ scholar?hl=en\&as_sdt $=0 \% 2 \mathrm{C} 5 \& \mathrm{q}$ $=$ Schein $\% 2 \mathrm{C}+\mathrm{E} .+\mathrm{H} .+\% 282010 \% 2$ 9.+Organizational+culture + and +1 eadership+\%28Vol.+2\%29.+John+ Wiley+\%26+Sons.\&btnG=

39. Shahzad, F., Iqbal, Z., \& Gulzar, M. (2013). Impact of organizational culture on employees job performance: An empirical study of software houses in Pakistan. Journal of Business Studies Quarterly, 5(2), 56. Retrieved from http://jbsq.org/ wp-content/uploads/2013/12/December_2013_4.pdf

40. Shields, J., \& Brown, M. (2015). 6 Reviewing and developing employee performance. Managing Employee Performance \& Reward: Concepts, Practices, Strategies, 140. Retrieved from https://scholar. google.com/scholar?hl=en\&as_sd $\mathrm{t}=0 \% 2 \mathrm{C} 5 \& \mathrm{q}=$ Shields $\% 2 \mathrm{C}+\mathrm{J} . \% 2 \mathrm{C}$ $+\% 26+$ Brown $\% 2 \mathrm{C}+\mathrm{M} .+\% 282015$ $\% 29 .+6+$ Reviewing+and+develop ing+employee+performance. $+\mathrm{Ma}$ naging+Employee+Performance+ $\% 26+$ Reward $\% 3 \mathrm{~A}+$ Concepts $\% 2 \mathrm{C}$ + Practices $\% 2 \mathrm{C}+$ Strategies $\% 2 \mathrm{C}+1$ 40.\&btnG=

41. Stewart, G. L., \& Barrick, M. R. (2000). Team structure and performance: Assessing the mediating role of intrateam process and the moderating role of task type. Academy of management Journal, 43(2), 135-148. Retrieved from http://psycnet.apa.org/record/2001-14441-001

42. Wallach, E. J. (1983). Individuals and organizations: The cultural match. Training \& Development Journal. Retrieved from http://psycnet.apa.org/record/1983-22213-001

43. VandeWalle, Don, William L. Cron, \& John W. Slocum Jr. (2001). The role of goal orientation following performance feedback. Journal of Applied Psychology, 86(4), 629. Retrieved from https://www.wku. edu/cebs/doctorate/documents/ readings/vandewalle_etal_1996_ role_of_goals_orientation.pdf

44. Williams, L. J., \& Anderson, S. E. (1991). Job satisfaction and organizational commitment as predictors of organizational citizenship and in-role behaviors. Journal of management, 17(3), 601-617. Retrieved from http://psycnet.apa. org/record/1992-07360-001 